\title{
The Hazards of the Use of English as a Default Language in Analytic Philosophy: An Essay on Conceptual Biodiversity
}

\author{
Christoph Harbsmeier \\ Epistemology recapitulates philology. ${ }^{1}$ \\ QUINE, Word and Object, p. vi.
}

The hazards of the use of English as a default language in analytic philosophy are obvious to everyone except mainstream analytical philosophers. ${ }^{2}$ The uncanny conceptual resemblance between what one is told about Jerry Fodor's universal Language of Thought and current globalese basic academic English calls for reflection. ${ }^{3}$

One might suggest, by way of an historical explanation, that after all Latin was used as the unquestioned default language in medieval analytic philosophy just as globalese koinē American English is used today. But as we shall see presently below, such an explanation would commit a grave injustice against Danish medieval philosophical thoughtfulness and methodological stringency.

1 I offer these freewheeling reflections in homage to my dear friend Albert Hoffstädt. As we might have said: Dulce est desipere in loco. And: Desipere est semper sapere. Kai summanēnai d'enia dei. Albert's cosmopolitan Latinate friendship and his inimitable Greek parrēsia, over many decades, continues to enrich the lives of many of us.

2 For example: would philosophy be quite the same with Chinese as the default language, where Americans would have to make do as best they can with a foreign language just as the Chinese and the French philosophers have to do today if they would like to be taken seriously in the profession? There is much to worry about here, even from a purely philosophical point of view. Some of the purely practical general problems raised by the hegemony of basic koine English in academia are memorably summarized by Eve Seguin under the title: Les effets délétères de l'hégémonie de l'anglais sur la recherche. (url: <https://www.acfas.ca/publications/decouvrir/2015/o4/quand-english-rime-avec-rubbish>)

3 For a survey of the history of the idea of Mentalese or oratio mentalis (confidently disregarded by Jerry Fodor), see Claude Panaccio, Le discours intérieur: De Platon à Guillaume d'Ockham (Paris: Editions Seuil, 1998). 
Professionals in the Philosophy of Mind have learned to be utterly unperturbed by the fact that Gilbert Ryle's The Concept of Mind sells in Germany as Die Philosophie des Geistes, in France even as La philosophie de l'esprit, and in Russian still more ominously as what I suppose might naturally translate into English as The Concept of Consciousness. ${ }^{4}$ Such is also the current state of the art in analytical philosophy more generally. ${ }^{5}$

"Philosophy," at least, one might be tempted to say, is found in a very large number of "major" languages of the world. But in fact the word "philosophy" recurs in so many languages of the world exactly because the concept of philosophy was sufficiently alien to all those cultures which have borrowed that alien word "philosophy" from the Greeks. Like the Romans, and for that matter the Arabs as well as the English. Sound philosophy should involve a thorough analysis of the reasons when and why so many rich languages have even needed to literally borrow a Greek word and were unable to coin a less obviously arcane and outlandish loan translation. The historical cultural anthropology of philosophy should be a matter of basic philosophical concern.

A concept like that of "knowledge" raises less obvious but no less fundamental problems. Since we have a word like "knowledge" in English, it is assumed by professional epistemologists like Ernest Sosa that there is an issue out there in philosophy and not in mere English philology. But "knowledge" might indeed also very much be a matter of the cognitive ethnography of speakers of English. ${ }^{6}$

4 Ponyatie soznaniya (Moscow: Ideya-Press, 200o). The best bilingual dictionary of Russian that I know of is the "Large Russian-Chinese Dictionary of the New Epoch (Большой русско катайский толковый словарь новой эпохи [Peking: Commercial Press 2014], 7576 pages), and it supplies the following modern Chinese glosses for soznanie: 知覺, 意識, 感覺, 神 志, 覺悟 (p. 6052). This is not the place to discuss the detailed meanings of these semantically complex Chinese terms. Suffice to say that none of them would be glossed by "mind" in any Chinese-English dictionary. And Professor Laier's book—and Laier is Ryle's Chinese name - sells under the name Xin de gainian 心的概念 (published Peking, 2011 and Shanghai, 1988), which any unsuspecting Chinese reader would tend to understand as "The Concept of the Heart" - until perchance instructed to do otherwise by bilingual speakers of Chinese.

5 Linguists have essentially the same problem as philosophers. However, linguists are at least trying to face up to the obvious problem. See, for example, Martin Haspelmath, "Comparative Concepts and Descriptive Categories in Cross-linguistic Studies” Language 86 (2010): 663-87, who makes a valiant effort in this direction. French having no notion quite like the English "language," only langue, langage, and parole, each of which has its specific excruciating conceptual quirks, any general linguist worth his salt is fortunately expected to be ready to discuss in detail the problems raised by the case of French.

6 Sosa writes: "Given a system of reasoning in competition with ours, how do we defend our preference for our own? The analytic epistemologist proposes that we engage in conceptual analysis, aiming to elaborate a criterion of rightness for systems of reasoning. With this criterion, we can then assess our system and compare it with competitors." (Ernest Sosa, "A Defence 
I have no doubt that many languages share with English the complex language game of using some word relevantly like "knowledge" to refer to a BELIEF that a PROPOSITION is TRUE and that BELIEF being (perhaps even: SCIENTIFICALLY Or STRICTLY) JUSTIFIED and that BELIEF being PRESUPPOSED by a PUBLIC.

For players of this complex cognitive game it is required that they share the following concepts:

PROPOSITION, TRUTH, BELIEF, JUSTIFICATION, PRESUPPOSITION, GENERAL PUBLIC.

The game is most enjoyable to play when among the players

1 , the contested and problematic nature of all these six concepts is not focused (even better when not understood at all), and when

2 , it is assumed that the game is universal, in the sense that it is played with an intended GENERAL PUBLIC that consists of the world's cognitively non-deficient humans capable of clear logical thinking. ${ }^{7}$

Now one might think that such matters as propositions (p, q, r) and matters of true and false (T, F) are adequately dealt with in what is known as the "firstorder propositional calculus" in logic. But of course the abstract algebra of that calculus has no relation to what we call propositional logic until its symbols $\mathrm{p}$, q, etc., as well as the symbols $\mathrm{T}$ and F, are satisfactorily interpreted in a way that ensures what is known as the "material adequacy" of the theory. And here, of course, English truth will be no more decisive than Russian pravda "truth" versus istina "Truth," ${ }^{8}$ or the less substantive distinction Latin makes of veritas

of the Use of Intuitions in Philosophy," in Stich and His Critics, ed. Dominic Murphy and Michael Bishop [Oxford: Wiley and Blackwell, 2009], 101). Naturally enough, this conceptual analysis is to be conducted in American English for Ernest Sosa. And that exactly is the problem with his approach that is never sufficiently focused.

7 David Papineau refuses to join the game and he thinks it is a waste of time: "Far from being a touchstone of the truth, knowledge is a stone-age concept that harms our dealings with the modern world" (<https://aeon.co/essays/knowledge-is-a-stone-age-concept-were-better-offwithout-it>). I am in enthusiastic agreement with this, but the reference to the stone age is deeply misleading from the point of view of conceptual history. We know nothing of stone age epistemic notions. The impact of Plato's Theaitetus on epistemic cognitive history has long been recognized and described.

8 Anna Wierzbicka, "Russian Cultural Scripts: The Theory of Cultural Scripts and Its Applications," Ethos 30.4 (2002): 401-32, esp. 407ff. The literature on istina versus pravda is vast, and occasionally it is indeed of profound philosophical interest. Cognitive and conceptual anthropology is essential to philosophy. 
"truth, the feature of being true" as opposed to verum "what is true," and the like.

Such a satisfactory interpretation will have to be done in a way that is not in itself a part of the abstract algebra in the first-order propositional calculus on the one hand, and not any idiosyncratic part of English or Russian only. The analysis has to aim to be overexplicit and metalinguistic, at least in aspiration.

In short: the abstract algebra in first-order predicate calculus is abstract in a sense that first-order predicate logic is not.

The "material adequacy" of first-order predicate logic thus resides in the contingent fact that words like "if," "or," and "and" are found to have certain standard uses that are adequately analyzed/modelled by certain symbols that may be formally defined in that calculus.

In much the same way, the "material adequacy" of the abstract algebra in natural number theory depends on the fact that some common uses of common words like "one," "two," "three," etc. seem adequately analyzed/modelled by that calculus. And, of course, until such a satisfactory interpretation is given and justified, the abstract algebra in natural number theory cannot be taken to be about numbers at all.

In short: The abstract algebra of natural number theory itself is not about numbers. It has been satisfactorily applied to natural numbers, but the algebra itself is more abstract than arithmetics.

For a satisfactory clarification of what a proposition is, or what it is to be true for a proposition, we cannot turn to the propositional calculus. One might feel the need to turn to Alfred Tarski and Donald Davidson and the Convention $\mathrm{T}$.

\section{Alfred Tarski and Donald Davidson on the Convention T}

Using the symbol 'Tr' to denote the class of all true sentences, the above postulate can be expressed in the following convention:

CONVENTION T.

A formally correct definition of the symbol ' $T r$ ', formulated in the metalanguage, will be called an adequate definition of truth if it has the following consequences:

$(\alpha)$ all sentences which are obtained from the expression ' $x \in \operatorname{Tr}$ if and only if $p$ ' by substituting for the symbol ' $x$ ' a structural-descriptive name of any sentence of the language in question and for the symbol ' $p$ ' the 
expression which forms the translation of this sentence into the metalanguage; ... (Tarski, CTF p. 188) ${ }^{9}$

Tarski studiously avoided declaring his metalanguage to be Polish or later German anywhere in his work as far as I know.

Let us try to approach the problem from a quite different angle, by returning to the idea of a semantical definition as in $\S 1$. As we know from §2, to every sentence of the calculus of classes there corresponds in the metalanguage not only a name of this sentence of the structural descriptive kind, but also a sentence having the same meaning.... In order to make clear the content of the concept of truth in connexion with some one concrete sentence of the language with which we are dealing we ... take the scheme [' $\mathrm{x}$ is a true sentence if and only if $\mathrm{p}$ '] and replace the symbol ' $x$ ' in it by the name of the given sentence, and ' $p$ ' by its translation into the metalanguage. All sentences obtained in this way ... naturally belong to the metalanguage and explain in a precise way, in accordance with linguistic usage, the meaning of phrases of the form ' $x$ is a true sentence' which occur in them. Not much more in principle is to be demanded of a general definition of true sentence than that it should satisfy the usual conditions of methodological correctness and include all partial definitions of this type as special cases; that it should be, so to speak, their logical product. At most we can also require that only sentences are to belong to the extension of the defined concept.... (CTF, p. 187)

In the Postscript, the central theorem of $\S_{5}$ is withdrawn and replaced by the theorem now familiar to logicians as Tarski's Theorem, saying roughly that truth is definable for an object-language if, but only if, the metalanguage in which truth is to be defined is "essentially richer" than the object-language; cf. CTF, p. 273 .

Donald Davidson summarizes:

According to Tarski's Convention T, a satisfactory theory of truth for a language L must entail, for every sentence s of $\mathrm{L}$, a theorem of the form "s is true if and only if $\mathrm{p}$ " where ' $\mathrm{s}$ ' is replaced by a description of $\mathrm{s}$ and ' $\mathrm{p}$ ' by

9 Alfred Tarski, "The Concept of Truth in Formalized Languages," in Logic, Semantics, Metamathematics (Oxford: Clarendon Press, 1956; henceforth CFT), 187-88. See also Tarski, "The Semantic Conception of Truth and the Foundations of Semantics," Philosophy and Phenomenological Research 4 (1944): 341-75, esp. 351. 
$s$ itself, if L is English, and by a translation of s into English if $\mathrm{L}$ is not English. ${ }^{10}$

Translatability into English is declared to be the standard by which candidature for being true or false is to be judged.

Davidson states elsewhere that "the notion of translation ... has no precise or even clear application to natural languages." ${ }^{11}$ I conclude that according to Davidson himself, at the philosophically substantial point of its definition the Convention $\mathrm{T}$ is "neither precise nor even clear." The Norwegian philosopher Arne Næss, who knew Alfred Tarski well, has pointed this out a long time ago, ${ }^{12}$ and I am told that Tarski acknowledged the problem in two postcards. I do wish I had asked Arne Næss about this when we were friends and colleagues in Oslo. ${ }^{13}$

Davidson basically agrees with Tarski: “Tarski was right, I think, in proposing that we should think of natural languages as essentially intertranslatable (though I don't see why this should require word-by-word translation). The proposal idealizes the flexibility and expandability of natural languages but can be justified by a transcendental argument." ${ }^{14}$

The anthropologist Mary Douglas comments on this kind of thinking in Donald Davidson and Quine with a reference to their "provincial logic": "The better the translation, the more successfully has our provincial logic been imposed on the native thought." ${ }^{5}$ Mary Douglas does not, I think, rely on the

10 Donald Davidson, "On the Very Idea of a Conceptual Scheme," Proceedings and Addresses of the American Philosophical Association 47 (1973-1974): 17. (Bolding is mine!)

D. Davidson, "The Method of Truth in Metaphysics," in Inquiries into Truth and Interpretation (Oxford: Clarendon Press, 1984), 204.

Arne Næss, "Truth" as Conceived by Those Who are not Professional Philosophers (Oslo: I kommission hos Jacob Dybvad, 1938), and "Empirical Semantics," in Philosophy and Grammar, ed. G. H. von Wright, Stig Kanger, and Sven Öhman (Dordrecht: Reidel, 1980), 135-55. See also The Selected Works of Arne Ncess, ed. Alan Drengson in cooperation with the author, 10 vols. (Dordrecht: Springer, 2015).

For detailed discussion of Arne Næss's contributions, see Joseph Ulatowski, "Ordinary Truth in Tarski and Næss," in Uncovering Facts and Values, ed. Adrian Kuzniar and Joanna Odrowaz -Sypniewska (Leiden: Brill, 2016), 67-9o, and Robert Barnard and Joseph Ulatowski, “Tarski’s 1944 Polemical Remarks and Næss' “Experimental Philosophy,"” Erkenntnis 81 (2016): 457-77, and now more generally Ulatowski, Commonsense Pluralism about Truth: An Empirical Defence (London: Palgrave, 2017).

14 Davidson, "In Defence of Convention T," in Inquiries into Truth and Interpretation, 72.

15 Douglas, Implicit Meanings: Selected Essays in Anthropology (London: Routledge, 1999), 252-53. The quotation continues memorably: "So the consequence of good translation is to prevent any confrontation between alien thought systems. We are left as we were at the 
any confused relativistic notion of "provincial logic" according to which every culture might come with its own self-contained incommensurate peculiar logic. The case of bilingualism is quite enough to show that confrontation between alien thought systems is real as long as it does not involve internalised notion that one idiom is the measure the conceptual or semantic well-formedness of all others.

However this may be, Davidson's summary of Tarski seems in other ways curiously inadequate. Tarski never redefined his (Polish) metajazyk as being English after the American victory in the Second World War. He wrote before the effects of the Second World War on the monopolistic predominance of English in academia.

On the other hand, Tarski maintained specific views on lexical equipollence or intertranslatability between colloquial languages: "A characteristic feature of ordinary language (in contrast to various scientific languages) is its universality. It would not be in harmony with the spirit of this language if in some other language a word occurred which could not be translated into it: it could be claimed that if we can speak meaningfully about anything at all, we can also speak about it in colloquial language." (СтF, 164)

Fortunately, Tarski's position on lexical equipollence and Donald Davidson's claim on translatability into English are open to empirical investigation. For example, it might appear that the Greek word philosophia was untranslatable into Latin, as we have noted above. The Roman solution was to invent a new Latin word philosophia which the speakers of Latin meant to understand exactly as the Greeks understood their word philosophia. If the possibility of extensive lexical, morphological, syntactic, and all manner of idiomatic borrowing were to be considered as an acceptable way of assuring equipollence between languages, then many problems would appear to disappear.

Consider now the following German sentences:

A. So etwas wird man doch wohl mal sagen müssen können dürfen wollen sollen!

SUCH SOMETHING ONE SURELY PRESUMABLY ONCE SAY MUST CAN MAY WANT-TO SHOULD

B. Das ist nun ja aber doch eben leider auch fast schon ueberhaupt kaum weiterhin noch recht eigentlich sozusagen wirklich vorbehaltslos zu glauben.

outset, with our own familiar world divided by its established categories and activated by the principles we know. This world remains our stable point of reference for judging all other worlds as peculiar and other knowledge as faulty." 
As for the second German sentence B, I am unable to attempt even any approximative mot-à-mot translation at this point: I must leave this huge task to a separate occasion. ${ }^{16}$ By the standards of Davidson's reformulation of "Convention T," I fear, the above sentences A and B would seem not to be semantically well-formed. And I suggest that this should worry analytical philosophers working in the tradition of Davidson.

When I presented Donald Davidson with such examples while we were colleagues in the Department of Philosophy at Berkeley, he pointed out with relish that to the extent I could show that these examples were convincing, I would have refuted my contention that these were relevant cases of untranslatability. He did add that in his view paraphrase must count as translation. A convincing paraphrase of the examples I then provided, to illustrate this ubiquitous possibility of paraphrase would have helped considerably, I thought.

I shall not pursue this matter in detail on this occasion. Suffice to say that anthropologically relevant paraphrasability in principle is best demonstrated by paraphrase of problematic examples in practice. The theoretical observation that as long as a people have Scheffer's stroke they are able, in principle, to express all of the propositional calculus is of strictly limited relevance. As Hans Reichenbach observes with his admirable bland directness: "The reducibility of all other operations to the stroke operation has, of course, only a theoretical interest. The resulting formulas (sic!) are so complicated that the use of other signs is preferable."17 The theoretical possibility of a paraphrase of B would have to be discussed on the basis of the critical discussion of a philosophically satisfactory and philologically successful explicit attempt to provide one. The

16 Here I shall also need to discuss the translatability of Jerry Fodor's splendid example "antianti-anti-missile-shield-shield-shield" into classical and also modern Chinese. See Jerry Fodor and Ernest Lepore, The Compositionality Papers (Oxford: Oxford Univ. Press, 2002), $1-2$.

17 Reichenbach, Elements of Symbolic Logic (New York: The Free Press, 1947), 44. On perceived limits of translatability, see, e.g., Bronisław Malinowski, Coral Garden: A Study of the Methods of Tilling the Soil and of Agricultural Rites in the Trobriand Islands (Vol II: The Language of Magic and Gardening) (London: Unwin Brothers, 1935), Div.2: "The Translation of Untranslatable Words." See also Anna Wierzbicka, Imprisoned in English: The Hazards of English as a Default Language (Oxford: Oxford Univ. Press, 2014) and Howard Rheingold, They Have a Word for It: A Lighthearted Lexicon of Untranslatable Words and Phrases (Louisville, Ky: Sarabande Books, 200o), bibliography, 267-79, with its instructive word index on pp. 281-84. For untranslatability in philosophy there is the much more ambitious and more radically chaotic Vocabulaire Européen de philosophies. Dictionnaire des intraduisibles, ed. Barbara Cassin (Paris: Robert, 2004), which has been delightfully mistranslated into English and published by Princeton Univ. Press. 
philosophical issue will then have to be discussed on the basis of advanced logically explicit philology. Quod erat demonstrandum.

Jerrold Katz's insistence on effability in principle is philologically and empirically — and therefore also philosophically —anemic, as it were, until it includes a discussion in full detail of the apparent difficulties of translation or paraphrase into English. ${ }^{18}$ Since I am personally incapable of providing so much as a mot-à-mot literal rendering of any sort I cannot be of much fullblooded help here. I can only lamely submit that B does make good sense to me, and that as a non-native speaker of English I have great trouble providing an English paraphrase to help in the discussion of B.

\section{Ernest Sosa on Knowing}

As I understand Sosa in discussion, he assumes that the problem of knowledge is not parochial to English or to languages like English, but somehow languageindependently given..$^{19} \mathrm{I}$ find it impossible to rise to the level of focusing on any such language-independently given object of thought, in propositional logic as in epistemology.

Any philosophically precise definition of knowledge is in my view stipulative: it creates an object of thought per definitionem. Such exact philosophical definitions are not the definitions of any well-defined given conceptual object of thought préalablement donné au delà du langage.

The stipulative definition of knowledge as based on the notion that belief qualifies as knowledge (justified, warranted) in virtue of its deriving from a reliable process designed to lead to the discovery of truth is unobjectionable, and is certainly not in any conflict with another stipulative definition of knowledge as a belief that fundamentally coheres with all other confident beliefs of some sort.

The question, of course, of which of these stipulative definitions-if any! best cover basic core meanings of the English word know/knowledge, the

18 Jerold Katz, The Metaphysics of Meaning (New York: Bradford Books, 1992), and idem "Effability and Translation," in F. Guenthner and M. Guenthner-Reutter, Meaning and Translation, Philosophical and Linguistic Approaches (New York: New York Univ. Press, 1978), 191-235.

19 On empirical aspects of epistemology, see Sosa, "Experimental Philosophy and Philosophical Intuition," Philosophical Studies 132 (2007): 99-107; idem, "A Defense of the Use of Intuitions in Philosophy," in Stich and His Critics, 101-12; and idem, "Intuitions and Meaning Divergence," Philosophical Psychology 23 (2010): 419-26. 
German Wissen versus Erkenntnis, ${ }^{20}$ the Russian words znat'versus vedat', the modern Chinese zhidao versus xiaode, the classical Chinese zhi, the classical Latin scire, and so forth, is philological as well as philosophical and does deserve close attention, especially with regard to the further question of how generally anthropologically representative these particular words are within the wide field of historical and comparative cognitive ethnography. But to hypostatize and conceptually reify a concept like knowledge is quite as arbitrary as it would be to assume that there somehow "is" somewhere out there some Justice waiting to be studied and adequately discussed and defined by Plato or John Rawls. For a comparatist student of conceptual history, it stands to reason that Archelaus (fl. 450 BC) made an important basic point when he claimed that "what is just and what is base depends not upon nature (phusei) but upon convention (nomōi)." ${ }^{21}$ And the fundamental cognitive contrasts between such conventions merit philosophical attention.

\section{Philosophical Fieldwork in the Cognitive Ethnography of Classical Chinese}

It might seem that epistemology is about something very important, namely knowledge - which I would want to try to distinguish carefully from the knowing of it.

20 It seems significant that even the truly brilliant book by Myles Burnyeat, The Theaitetus of Plato (Cambridge: Cambridge Univ. Press, 199o), never stops to consider that fact that the theologian and hermeneutic philosopher Friedrich Schleiermacher in his time came to prefer Erkenntnis as a translation for the issue of epitstēmē in his famously literal translation of the Theaitetus. To cut a long story short: Plato's ultimate issue is not the kind of Wissen that snow is white (for this Plato has the very current oida "I know" and the much rarer abstract eidēsis "knowledge). Plato's ultimate concern is taken to be the Erkenntnis of what exactly it is, in a deep scientific sense, for snow to be white. Epistēmē, then, would not be anything like just knowing something is the case. Epistēmē, in the sense that Plato obsesses with is more like the getting to the bottom of how exactly something is really to be understood. In any case, one understands the word epistēme to the extent that one has learned to distinguish it from its many near-synonyms in ancient Greek generally or in a given text.

$21 \quad$ See Diogenes Laertius, Lives of Eminent Philosophers, tr. R.D. Hicks (Cambridge, Mass.: Harvard Univ. Press, Loeb Classical Library, 1980), 1: 147. For ancient detail on this point, see Sextus Empiricus, Outlines of Skepticism, tr. Julia Annas and Jonathan Barnes (Cambridge: Cambridge Univ. Press, 2000), 194. One does not have to be an ethical skeptic or a relativist of any ilk in order to respect the philosophical importance of cognitive and conceptual diversity. 
In "Conceptions of Knowledge in Ancient China,"22 I myself have made a first tentative effort to put Chinese epistemological reflection in a philological and and historical as well as philosophical context.

When Zhuangzi ch. 1 says 小知不及大知 “Little $z h i$ (knowledge) does not reach great $z h i$ (knowledge)," the question that needs to be addressed is which (if any!) of the following that each of these two tokens of $z$ hi should be taken to be referring to:

A. what one knows to be true

B. the knowing of what one knows to be true

C. the capacity for knowing things to be true or false

D. the proper understanding of the inner workings and dynamics of things

E. the wisdom as a general capacity for such understanding of the inner workings and dynamics of things as formative of one's "philosophy of life"

In interpreting this gnomic statement, one is in the middle of complex issues of classical Chinese philosophical philology, before one even begins to have any well-defined abstract object of thought to philosophize and theorize about with any theoretical precision at all. One is faced with a pretty radical philosophical indeterminacy of discourse which leads to a danger of radical indeterminacy of translation. And as Quine has famously demonstrated, such philosophical inderdeterminacy and such indeterminacy of exact philosophical interpretation is very much present in English, just as we here find it even manifest in classical Chinese.

Consider the opening paragraph of Zhuangzi ch. 7 with Burton Watson's translation:

一以已爲馬, 一以已爲牛。其知情信, 其德甚真。

once take self consider.as horse. once take self consider.as ox. his KNOw truly reliable, his virtue intensely genuine.

“(The Clansman T'ai, now-he lay down peaceful and easy; he woke up wide-eyed and blank.) Sometimes he thought he was a horse, sometimes he thought he was a cow. His understanding was truly trustworthy, his virtue was perfectly true."23

22 Harbsmeier, "Conceptions of Knowledge in Ancient China," in Epistemological Issues in Classical Chinese Philosophy, ed. Hans Lenk and Gregor Paul (Albany: State Univ. of New York Press, 1993), 11-31.

23 Watson, Chuang-tzu: Basic Writings (New York: Columbia Univ. Press, 1964), 89. A quick glance across other translations shows up the philosophical uncertainties regarding the interpretation of this passage. Herbert Giles (London: Allen and Unwin, 1926), 86: "his wisdom was above suspicion." The Polish translators (Czuang-tsy [Warsaw: Panstwoe Wydanictwo Naukowe, 1953], 109) translate xin 信 as wiarogodny “plausible." A. C. Graham, 
Mr Tai's opinions or beliefs (what he yi wei 以爲's) are here referred back to as $q i z h i$ 其知 “his $z h i$ UNDERSTAND>KNOW ??his understanding??"

When zhi 知 is used in contrastive parallelism with the body, the English translation that recommends itself is not in any sense "knowledge" but rather something like the capacity of "understanding," German Verstand. As in the famous phrase from Zhuangzi 1:

豈唯形骹有龍盲哉? 夫知亦有之. “Why should there only be deafness and blindness of our physical frame. As for one's understanding, such conditions also exist."

In nominal use, the wisdom or knowledge referred to by zhi 知 is typically (but not always) practical, even in Zhuangzi 10:

出後, 義也; 知可否, 知也; 分均, 仁也. “(As a robber) getting out last is dutifulness; understanding the possibilities/acceptabilities is wisdom $(z h i)$; dividing the loot evenly is benevolence."

The counter-examples to this in Zhuangzi and elsewhere, where the issue is indeed theoretical and about the adequacy of human knowledge, will be discussed by others. My purpose here is to provide some impression of the philological and lexicographic context of such uses of $z h i$ 知.

I note in passing that the question of exactly which of these uses of $z h i$ "knowledge" would naturally translate into ancient Greek epistēme and which into ancient Greek gnōmē is of some interest for the historically well-orientated epistemology.

\section{General Considerations on Philosophical Cognitive Ethnography}

From the point of view of cognitive science I find, to begin with, it is entirely plausible that there are richly expressive languages in which one can only be "quite sure," "quite certain," "perfectly convinced," and so on, but where one never engages in the kind of "knowing" that imputes presuppositions about truth to any audience.

Chuang-tzǔ: Inner Chapters (London: Allen and Unwin, 1981), 94 has "His knowledge was essential and trustworthy." Wang Rongpei (Zhuangzi [Changsha and Beijing: Hunan People's Publishing House and Foreign Languages Press, 1999], 114) translates freely thus: "With true virtue, he had never troubled himself with the human world," and into modern Chinese as “他的智慧和感情實在而不虛僢.” Victor Mair (Wandering on the Way: Early Taoist Tales and Parables of Chuang Tzu [Honolulu: Univ. of Hawaii Press, 1994], 66) disregards the reflexive pronoun $j i$ 已 and translates: “Clansman T'ai's dozing was so contented and waking so peaceable that at one point you might think he was a horse and at the next moment a cow. His knowledge was trustworthy, his integrity very true." 
I hope I can be forgiven if I begin with some very unprofessional reflections from an outsider, before I go on to the main philological part of my contribution.

I ask myself this: exactly how widespread is some kind of lexicalized practice (or as Wittgenstein would have it, the language game) of concurrently believing propositions to be true, believing that belief to be justified (in whatever way), and presupposing that belief should be universally shared by an intended general public (however circumscribed)?

Now believing, justifying, presupposing, shoulding, as well as being shared, are matters of of different kinds, levels, and degrees, in important ways. Different languages may elaborate and lexicalize such matters to widely differing degrees and in widely different manners.

And here, then, is my hunch within the wide field of cognitive ethnography:

There might very well be linguistic NON-EPISTEMESE communities who do use non-factive verbs, like FEEL SURE THAT, without engaging in the problematic and complex game of committing themselves to any presumed universal or general consent. And would not lexicographers, in any such language, cite the verb BE SURE THAT as the local word for KNOW, faute de mieux? Would not the inevitable New Comprehensive English-Non-Epistemese Dictionary reasonably cite the Non-Epistemese expression for "be sure that, etc.," as the local word for the English "to know"? Remember: the lexicographic horror vacui is endemic in lexicography: dictionaries feel obliged to list up translations of untranslatables in order to avoid a lexical void, or a lexical gap. Lexicographers do not like to acknowledge professional failure to deliver. Philosophers would trust them at their peril.

The scope of what is discussed by philosophy as theory of knowledge is very likely less than universal. The thought that English exhibits the essentially important features of human language sufficiently for the philosophy of language to be able to limit its attention to English is in my view a recent instance of wishful thinking with an old history.

One might also want to say that it was intellectual wishful thinking in the doctrine of the Danish logicians of the thirteenth century that everything important about language was in fact exhibited in the features of Latin (the Greek article, for example, they declared to be only a marginal feature of the basic system of human language). But neither Boethius of Dacia nor Johannes of Dacia $^{24}$ (nor indeed Thomas of Erfurt) were aiming at intellectual comfort

24 See Jan Pinborg, Die Entwicklung der Sprachtheorie im Mittelalter (Copenhagen: Verlag Arne Frost-Hansen, 1967), 26-30. There is a medieval Danish tradition along these lines, published as the Corpus Philosophorum Danicorum Medii Aevi, 6 vols. (Hauniae: apud 
over and above logical truth. They did indulge in wishful thinking. But at least they did their best to argue their case. The comparison with modern analytical philosophers is instructive on this point.

In my extensive tête-à-tête discussion with Professor Quine on these matters in the Faculty Club at Harvard some time in the early eighties, ${ }^{25}$ I opened the conversation with a fearless question: "Why," I asked, "are you not describing yourself as a 'philosopher of English' since that is what in effect you really are?" Quine seemed delighted by the challenge: "Point taken!" he said, apparently looking forward to a lively lunch. And I came away from that lunch happily convinced that Quine did not succumb to any wishful thinking concerning the representative status of the English language for philosophical concerns. On the other hand, he congenially insisted that the ball was in my court to demonstrate with logical clarity what the philosophical essentials were that needed to be learned from, for example, classical Chinese. He had been profoundly unimpressed by what he had been told so far. And I hate to admit that now, some thirty years later, the ball still remains where it was then.

Now Ernest Sosa identifies wishful thinking as follows: "There is such a thing as wishful thinking of a sort that aims at the intellectual comfort of the believer." ${ }^{26}$ Sosa continues to give an example: "For example, we are said to systematically overestimate our own merits. Such beliefs can aim at our comfort regardless of truth, which in some cases might not even be an aim, much less the aim."27 For my part, I take wishful thinking to consist in the wishful thinker being intellectually misled by a subconscious motivation which causes him to take what is merely desirable to be real. The wishful thinker clearly wishes he was not in this way being misled. And I believe as philosophers we should ensure that we are indeed not in this way intellectually misled into treating deep linguistic variation as irrelevant to the philosophy of language.

There is an interesting idiomatic feature in "knowing full well." For, knowing full well strongly invites a negative continuation. As in: Knowing full well that

G.E.C. Gad, 1955), where especially 1: $53^{-75}$ is relevant: utrum grammatica una apud omnes "Whether grammar is one in everyone." Sten Ebbesen, Dansk Middelalder-filosofi (Copenhagen: Gylderndals Forlag, 2002) provides a truly magisterial and eminently readable survey of the medieval Danish tradition of philosophy, for those who read Danish.

It was by the grace of my host in Cambridge, Betty Burch, that I met Quine for a two-anda-half-hour lunch à deux at the Faculty Club. I owe Betty Burch an eternal debt of gratitude for finding it in her heart to take the initiative to arrange this unforgettable meeting. (Betty Burch was married to the philosopher George Boswell Burch who wrote his Harvard Ph.D. thesis on the entirely pertinent subject, "The Epistemology of St. Bernard of Clairvaux").

26 Sosa, Knowing Full Well, 15.

27 Ibid. 
linguistic variation is relevant to the philosophy of language and doing nothing about it is, in my view, a dereliction of philosophical duty.

The philosophical duty I am thinking of here is the duty to cultivate philosophical fieldwork nourished by a spirit of logical analysis, coupled with patient literate philology, modern and ancient. ${ }^{28}$ Ultimately it involves the cultural anthropology of analytic philosophy, much in the spirit of Bronislaw Malinowski. This would involve a type of critique of language that goes beyond Fritz Mauthner (1849-1923) ${ }^{29}$ and the late Ludwig Wittgenstein, by taking philosophically seriously what Wilhelm von Humboldt investigated as die Verschiedenheit des menschlichen Sprachbaus, "the structural variability of human language." 30

What we need in the philosophical sphere is the fearless curiosity that Alexander von Humboldt displayed in the naturalist wealth of the Americas and of the vast lands of Russia. In these distant lands he found the following:

Spheniscus humboldti—known as the Humboldt penguin

Dosidicus gigas - known as the Humboldt squid Lilium humboldtii-known as the Humboldt lily

Phragmipedium humboldtii—known as the Humboldt orchid Quercus humboldtii-known as the Humboldt (Andean) oak Conepatus humboldtii-known as the Humboldt hog-nosed skunk Annona humboldtii-known as a Humboldt neotropical fruit shrub Utricularia humboldtii-known as the Humboldt bladderwort Geranium humboldtii-known as the Humboldt cranesbill Salix humboldtiana-known as the Humboldt South-American willow Inia geoffrensis humboldtiana-known as the Amazon river Humboldt dolphin.

28 My mentor Professor Günter Patzig provided a shining example of all of this in relation to Greek philosophy, at the Georgia Augusta University of Göttingen in the 196os.

29 For a brilliant essay on Fritz Mauthner, the disciple of the Vienna physicist Ernst Mach, as a major inspiration for Ludwig Wittgenstein, see Hans Sluga, "Wittgenstein and Pyrrhonism," ch. 5, in, ed., Pyrrhonian Skepticism, ed. Walter Sinnot Armstrong (Oxford: Oxford Univ. Press, 2004), 99-117. Fritz Mauther's relevant works include Beiträge zu einer Kritik der Sprache, 3 vols. (Leipzig: Felix Meiner, 1901-02), and his Wörterbuch der Philosophie: Neue Beiträge zu einer Kritik der Sprache, 3 vols. (Vienna: Böhlau Verlag, 1910). Many of Mauthner's other writings provide philosophical comic relief.

See Wilhelm von Humboldt, On Language: The Diversity of Language Structure and its Influence on the Mental Development of Mankind, tr. Peter Heath (Cambridge: Cambridge Univ. Press, 1988), and Christoph Harbsmeier, Wilhelm von Humboldts Brief an Abel-Rémusat und die philosophische Grammatik des Altchinesischen (Stuttgart: Fromann Verlag, 1979). 
Might there not be, in philosophy at least as much as in physical nature, unfamiliar things out there in distant parts that need-however!- to be approached in their own terms and by their own names, without superimposing Latinate or English nomenclature or assimilation on them? This is not a matter of mere intellectual politeness to the Other. What we really would need, after the Linguistic Turn, is a Copernican analytic revolution in analytical philosophy. But such grandiloquent talk sounds depressingly like modern academic self-advertising commodification of what is just a little worrying reflection on the current use of language in analytical philosophy.

What I am pleading for is not just a matter of paying great attention to other philosophical traditions. ${ }^{31}$ It is a matter of understanding how English cannot serve as any centre or point de départ for the description of all cognitive systems. We need to try to define the topology of the human cognitive space where English must show up as the very untypical case of a natural language that it manifestly is.

Pace Donald Davidson, English is not the measure of all things. ${ }^{32}$ And historical cognitive ethnography is relevant to philosophical epistemology.

The indispensable basis for any philosophy with global ambitions is a conceptual "experimental method" applied to the problems of conceptual diversity among human languages regarding not least of all the conceptual schemes of which one's own philosophical keywords are an integral part. ${ }^{33}$

$31 \quad$ Pleas for such a non-Eurocentric global perspective abound everywhere, East and West. But neither subsumption of other traditions under Western philosophical categories nor the exoticization of foreign concepts by the introduction of inscrutable neologisms are helpful. Current work is torn between the Scylla of subsumption and the Charybdis of exoticization. An escape from these two overfamiliar dangers might be found in Anna Wierzbicka's project of Natural Semantic Metalanguage, which aims to use configurations of "universal" primitive concepts to define all concepts, including the English ones. See Wierzbicka, Semantics: Primes and Universals (New York: Oxford Univ. Press, 1996). But this would involve, for example, the postulation of KNOW as a semantically non-complex prime, which I have found philosophically problematic if THINK is also taken as a primitive, since KNOwing under any analysis would have to be a hyponym of (some kind of) THINKing or BELIEVEing, and thus not a prime. For my own imperfect efforts to solve the problem, see Thesaurus Linguae Sericae (tls.uni-hd.de) and my chapter in the forthcoming Keywords in Chinese Culture, ed. Li Wai-yee and Yuri Pines (Hong Kong: Chinese Univ. Press).

32 On the difficult notion of "measure" as used here, see Protagoras of Abdera: The Man, His Measure, ed. Johannes M. van Ophuijsen, Marlein van Raalte, and Peter Stork (Leiden: Brill, 2013).

33 Raymond Williams, Keywords: A Vocabulary of Culture and Society (Glasgow: Fontana/ Croom Helm, 1976), deserves a successor that might attempt to take better account of conceptual diversity across cultures and also across history. 